But such are the limitations of an image-based art history in relation to the social history of art. Lee argues well in trying to interpret these gaps and lacunae in the historical evidence, and certainly does a good job in using the images for his defense. If some of the interpretations seem pressed, that makes the argument subject to further review and discussion by scholars. He is to be commended for attempting the difficult task of making sense of a clearly contradictory and complex history.

In essence, Lee's sweeping saga is emblematic of stronger currents in contemporary social art history. The social for Lee is a complex term, combining biography, iconography, institutional history, political history, and labour history, all with an attention to explaining how and what painting precisely meant at a given place and given time to a specific audience. That he takes as his subject the crucial period in U.S. labour history of the pre-World War II era is no coincidence. Rather, this period still has resonance with leftist and labour debates to our own day. Lee's text thus contributes to the problems and possibilities with which such leftism has to contend. Part of the remnants of this leftist moment is the continued deification of Rivera as an all-important artist. Few would disagree that Rivera was significant. But Lee gives us new material and a new context in which we can place the production and contribution of Rivera. As such, his text thoroughly debunks the notion of an iconic leftist "master" and instead shows the artist to be part and parcel of a much more complex, much more contradictory, and hence much more realistic moment in the cultural and political production of the left. These are actions and politics from which we can still learn.

Paul B. Jaskot, DePaul University

\title{
Fascinating Fascism in North America
}

Angelo Principe, The Darkest Side of the Fascist Years: The Italian-Canadian Press, 1920-1942 (Toronto: Guernica Press, 1999);

Philip V. Cannistraro, Blackshirts in Little Italy: Italian Americans and Fascism, 1921-1929 (West Lafayette, Ind.: Bordighiera Press, 1999).

Much of the Italian-American community (both academic and lay) remains fixated on the problems generated by HBO's television series, "The Sopranos," and the pervasive image of supposed Italian-American criminality. Less attention has been paid to another phenomenon, more disturbing even if more circumscribed by time: the Italian American community's support of Mussolini and fascism. Today, one can walk into a shop in New York's Little Italy and 
easily find shirts bearing Mussolini's image for sale.

That lacuna has now been filled by a short, though important, work by Philip V. Cannistraro, Distinguished Professor of Italian American Studies at Queens College and the Graduate Center of the City University of New York. An expanded version of a long essay that originally appeared in Renzo De Felice's journal, Storia Contemporanea, in 1995, Blackshirts in Little Italy is a study combining immigration history, contested political loyalties, and the emergence of an Italian American identity in the early years of the twentieth century. Based on extensive archival research - including the Archivio Centrale dello Stato and the Archivio Storico del Ministero degli Affari Esteri in Italy and the National Archives and FBI records in Washington Cannistraro meticulously reconstructs a lost epoch. Italians in America were torn: sentiment and nostalgia demanded loyalty to a nation that had - in effect - rejected them politically, culturally, and economically; their new country presented generous opportunities, but at a price.

Unlike earlier studies which have dismissed the influence of fascism on Italian Americans, Cannistraro shows how the fascist government made strident efforts to recruit both leading prominenti such as Generoso Pope (publisher of Il Progresso and other Italian-language newspapers) as well as the masses. Mussolini's representatives in America shrewdly played on the anxious (and new-found) nationalism of the Italian Americans. Fascist rhetoric appealed to Italian Americans, many of whom were suffering from overt discrimination; harking back to the glories of ancient Rome, Italo Balbo's flying squadron, and the Duce's declaration of an "African Empire" were powerful ingredients in an ideology of compensation.

It wasn't an easy task though. Although fascist squadristi could commit arson and murder with impunity in Italy, Mussolini's representatives and the Fascist League of North America had to tread softly in America. Besides a tradition of democracy and free speech, fascist penetration was limited to some extent by the efforts of Italian and Italian American anti-fascists such as Carlo Tresca and Gaetano Salvemini and organizations such as the Mazzini Society and the ILGWU.

It is disappointing that the study ends in 1929, for the next two decades saw conflicting emotions and politics among Italian Americans. Cannistraro ends with 1929 because that year saw the dissolution of the Fascist League of North America in the face of US government intervention. An argument can be made that many politically-active Italian Americans supported Mussolini and fascism, especially in 1935-1936 with the "victory" over the Ethiopians. Italian fascist intervention in the Spanish Civil War and the growing alliance with Hitler's Germany tempered that support and Italy's declaration of war against France on 10 June 1940 was met with widespread disapproval this side of the Atlantic. When the USA declared war on Japan, Germany, and Italy, Italian Americans universally declared allegiance to their new homeland. After the 
war, fascism was transformed - for some - into a "culture of nostalgia" in which Mussolini's only mistake was his alliance with Hitler. It is to be hoped that Cannistraro's excellent study will act as a catalyst for other scholars to pursue these neglected pages of history.

Angelo Principe's fine work takes up (in Canada) precisely where Cannistraro leaves off: the 1930s. Principe suggests several reasons why fascism failed to stir Italian Canadians in the 1920s: first and foremost being the political apathy of most Italian Canadians. But with the coming of economic depression and the Lateran Accords which reconciled the Vatican with the Italian State in 1929, Italians in Canada began taking a serious look at Mussolini's movement. Mussolini by 1930 had managed to "normalize" fascism. Accordingly, there was a "golden age" of fascism - or more accurately, the fascist press - in Canada from 1935 (the outbreak of the Ethiopian War) until 1938 (when the regime passed anti-Semitic legislation).

While it is surely an exaggeration to claim that a sympathetic press was the "darkest side" of the fascist era when political opponents were being arrested, exiled and assassinated, Principe does not over-exaggerate in his thoughtful arguments. His study centers on three Italian Canadian fascist newspapers: L'Italia in Montreal, Il Bollettino italo-canadese in Toronto, and L'Eco italo-canadese in Vancouver. As Principe writes, "Despite local differences, the three major newspapers played a decisive role in fostering fascism among Italians, in fiercely defending fascist ideology and policy, and in propagating the image of fascist Italy that was elaborated in the office of the Ministry of Popular Culture" (26). The birth, evolution and editorial policies of these papers form the heart of the work, while a useful introductory chapter sets the stage and a later chapter examines fascist anti-Semitism and its echoes in the Italo-Canadian press.

Italians in America and Canada were susceptible to fascist rhetoric of creating a new "fascist man and culture." Fascists in Italy and in the emigrant communities devised a brilliant strategy of conflating patriotism and fascism: the only patriotic Italian (and hence one who didn't betray la patria) was a fascist Italian. Leftists and democrats of all persuasions were suspect of betraying the motherland and all it stood for. Italianità and fascism became synonymous. Fascist newspapers were not the first to unequivocally support a political regime; as Principe mentions, "the history of ... the Italian press abroad cannot be dissociated from this multi-faceted and changing, but persistent, patriotic core by which the press has lived, and still lives, symbiotically" (37). Added to this was the support for fascism given by the Catholic Church, first in Italy and later in Canada.

Principe posits a convincing psychological portrait of Italian Canadians (which would apply equally well to Italian Americans): “... the web of individual interests (ambition, vanity, profit, and pride) and collective resentments (discrimination, both real and imaginary, unemployment, and 


\section{Left History 7.1}

exploitation) coalesced in the seemingly respectable form of "Italian patriotism" (61).

The Italian newspapers in Canada did not exist in a vacuum, but Principe only glancingly looks at the rest of the Canadian press. There was a vociferous press campaign in Canada against the Ethiopian War which forced the three Italian Canadian papers to defend the "Ethiopian adventure." They were enormously successful in rallying Italian Canadians to the "civilizing mission"; moreover, recent emigrants could be expected to be sympathetic to the fascist regime's argument that over-populated and poverty-stricken southern peasants needed colonies to alleviate conditions back home. But by the late 1930s that unified voice was strained by fascist Italy's anti-Semitism. $L^{\prime} E$ co of Vancouver made no editorial comments while Montreal's L'Italia dutifully followed the party line. But Toronto's Il Bollettino degenerated into a vicious anti-Semitic mouthpiece, worthy of the most fanatical nazi. To their immense credit, Italian Canadians did not sink to the level of $I l$ Bollettino and there are even heroic instances of Italian Canadians coming to the aid of Canadian Jews in riots.

Of the three, L'Italia of Montreal lasted the longest (1916-1940) while L'Eco Italo-Canadese lasted only four tumultuous years (1936-1940). In June 1940, when fascist Italy declared war on Britain (and technically Canada as well), the newspapers were closed and roughly 600 Italian Canadians were interned in camps, including members of the three newspapers discussed here (as well as some 99 Italian seamen who had the misfortune of finding themselves in Canadian ports when war was declared).

Cannistraro and Principe are to credited for offering a more balanced and complex portrait of Italians in North America and their relationship with Italian fascism. Usually, Italians in North America claim to have been innocent and that their internment - both in the USA and Canada - was an outrageous infringement of their civil liberties. While deplorable, the internment also netted fanatical fascists who were divided in their loyalties. Many of those interned where hardly as innocent as they liked to proclaim. In fact, Attilio Perilli of Il Bollettino continued to publish a fascist newspaper even in the Petawawa internment camp.

Principe promises a forthcoming volume on the Italian Canadian antifascist press and Cannistraro is training new Ph.D.s in New York so we can anticipate more fine work on these subjects in the near future.

Stanislao G. Pugliese

Hofstra University 